\title{
The Influence of Transformational Leadershipof Principals and Teacher Achievement Motivation on Teacher Teaching Performance At SMA Dirgantara Center
}

\author{
Sabaruddin Chaniago ${ }^{1 *}$,Widy Hastuty $\mathrm{HS}^{2}$,Nirmalasari ${ }^{3}$,Minasari Nasution ${ }^{4}$ \\ ${ }^{1234}$ Lecturers in Computerized Accounting, PoliteknikUnggul LP3M \\ North Sumatra Indonesia \\ ${ }^{*}$ Corresponding author: Sabaruddin Chaniago \\ Email: sabaruddinchaniago@gmail.co.id
}

\begin{abstract}
.
This research aims to findout the influence of transformational leadership and motivation to excel on teacher teaching performance at Dirgantara Senior High School Center. The population in the study was teachers at SMA Dirgantara Center which numbered 34 teachers, while the sample determination technique was. So the sample in this study was 34 people. This type of research is quantitative research. Quantitative research is a study that aims to find out the degree of relationship and pattern/form of influence between two or more variables, where by this research will be built a theory that serves to explain, predict and control a symptom. As for the data sources in this study from primary data and secondary data. Where is the primary data from observations, interviews and questionnaires? While secondary data can be from documented data.

Test results $(\mathrm{t})$ or partial tests show that transformational leadership has a positive and significant effect on teacher teaching performance as well as motivational variables that also have a positive and significant effect on teacher teaching performance. Simultaneously transformational leadership and motivation of achievement havea positive and significant impact on the teaching performance of teachers. The result of determination is obtained a correlation regression value of 0.770, meaning that together transformational leadership and motivation to excel against the teaching performance of teachers at SMA Dirgantara Center has contributed to a close and positive level. Then the determination coefficient $\left(\mathrm{R}^{2)}\right.$ is $0.566(56.6 \%)$. So it can be said that $56.6 \%$ variation of bound variables i.e. transformational leadership and motivation to excel on the model has a contribution to teacher teaching performance at SMA Dirgantara Center while the remaining $43.4 \%$ is influenced by other variables outside the model.
\end{abstract}

Keywords : Transformational Leadership, Accomplished Motivation,

Performance

\section{INTRODUCTION}

SMA Dirgantara Center is one of the educational institutions. SMA Dirgantara Center is one of the schools that has a vision and mission that is to create and produce quality human resources, nurture and pay attention to aspects related to improvement. Based on observations that researcher's do that the teacher's performance is not maximal in carrying out his duties and responsibilities. Where many teachers have a learning program plan (RPP) but are not run properly. For example, learning planning. Sometimes many teachers are unprepared or unable to complete the subject with an effective week of teaching. So this has an impact on subjects that are not achieved to be taught. Jaman is a method of learning teachers more in the presence of lectures or speeches in front of students. So in the process of teaching learning activities are more one-way that makes students do not have a strong courage to ask if there is a teacher's explanation that he does not understand.

A teacher's performance is heavily influenced by the principal's leadership style[1][2]. Assertiveness in leading tends to make teachers more eager to work even better[3].So far, the leaders at 
SMA Dirgantara Center are only busy managing affairs that are more economical than to foster teachers and students. The principal's activities only manage the program to help renovate the school building and so on. This is because the principal is also the chairman of the foundation. So it's no wonder that the model or her pinning style is following her own will and desires.

In addition to the principal leadership factor the next factor is the motivation of low teacher achievement. Good motivation will be able to improve a teacher's performance [4][5][6]. With high work motivation makes teachers more encouraged to teach as expected by the principal. So far, the teachers at SMA Dirgantara Center have not been maximal. A teacher how is it possible to improve his performance if the teacher is not given the opportunity to get further training or education. In other schools, teachers are given training held by the Education Department for free. In addition, teachers who have a wellconsidered performance are given a scholarship to continue further education.

\section{METHODS}

This type of research is quantitative. Quantitative method is scientific method because it has fulfilled the rules of concrete or empirical, measurable, rational and systematic. It is called a quantitative method because the research data is in the form of figures and analysis using statistics [7]. The population in this study was a teacher at SMA Dirgantara Center who numbered 34 people. In this study sampling techniques by means of saturated sampling.

Proper data collection is very important, because it determines the bad good of a study. Data collection is an attempt to obtain information materials and reality that is truly real and can be answered. The methods used in this study are:

\section{Observation}

Observations, also known as observations, include the activity of loading attention to an object using all sensory tools [7].

2. Interview (Interview)

Interviews is used as a deeper technique and the number of respondents issmall [8].

3. Questionnaire or Questionnaire

Questionnaires are a number of written questions used to obtain information from the respondent in the sense of reports about his personality, or things he knows[7]. In this study, questionnaires or questionnaires were used to collect data from respondents who worked at SMA Dirgantara Center.

This operational definition consists of two variables studied: free variables and bound variables. While the explanation of the operational definition of variables for each variable is as follows the operational definition in this study consists of two variables namely:

1. An independent variable (free) is a variable that affects the bound variable. As for this study, the free variables are transformational leadership and motivation to achieve.

2. Dependent variables (bound) are variables that are affected by free variables. If a free variable is leveled or lowered it will affect the bound variable. As for the bound variables that are teaching performance

\section{RESULT AND DISCUSSION \\ Description of Respondents \\ Characteristics of Respondents by Gender}




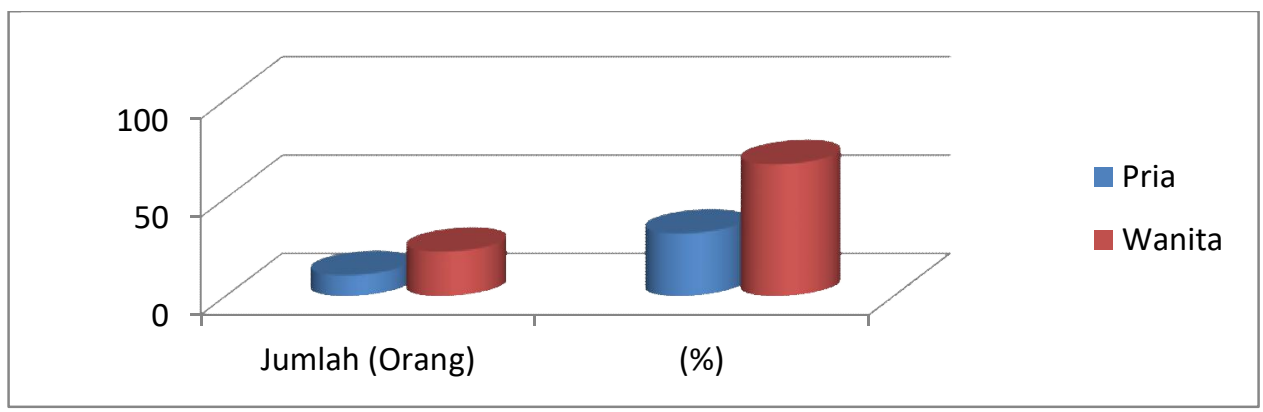

Figure 1.Characteristics of Respondents By Gender

Based on tables and graphs showing that respondents were 11 male (32.35\%) while women 23 (67.65\%). Characteristics of Respondents Based on Education Level

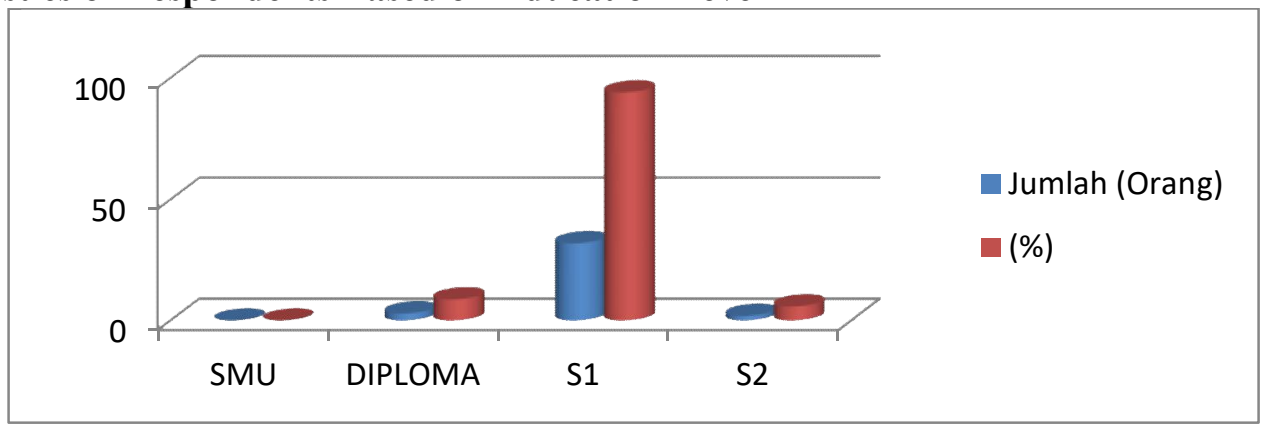

Figure 2.Characteristics of Respondents Based on Education Level

Based on the table and chart above it is known that all high school educated teachers are 0 people or $(0 \%)$, diploma-educated teachers number 3 teachers or $(8.82 \%)$, teachers who are 32 or $(94.11 \%)$ and teachers who are 2 years old or $(5.9 \%)$.

\section{Characteristics of Respondents By Age}

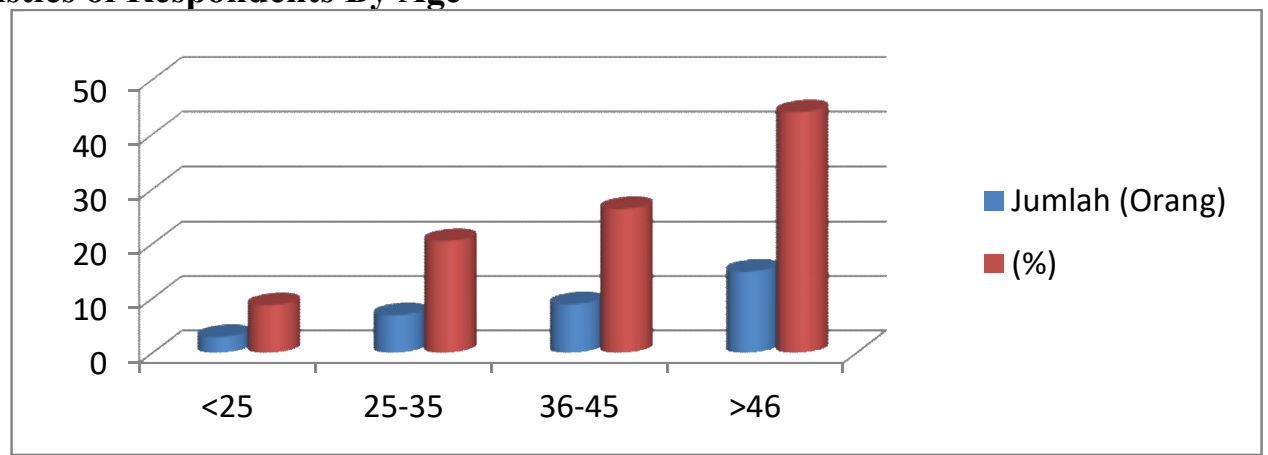

Figure 3.Characteristics of Respondents By Age

Based on the table and chart above it is known that teachers aged $<25$ years old numbering 3 people $(8.82 \%)$, teachers aged 25-35 years old number 7 people $(20.59 \%)$, teachers aged 36-45 are 9 people $(26.47 \%)$ and teachers aged $>46$ years old numbered 15 people $(44.12 \%)$.

\section{Determination Coefficient Value}

The correlation regression value of 0.770 , which means that together transformational leadership and motivation to excel against teacher teaching performance at SMA Dirgantara Center has contributed to a close and positive level. Then the determination coefficient $\left(\mathrm{R}^{2)}\right.$ is $0.566(56.6 \%)$. So it can be said that $56.6 \%$ variation of bound variables i.e. transformational leadership and motivation to excel on the model 
has a contribution to teacher teaching performance at SMA Dirgantara Center while the remaining 43.4\% is influenced by other variables outside the model.

\section{The Influence of Transformational Leadership on Teaching Performance}

In the study nilai its significance for transformational leadership variables (0.001) is smaller compared to alpha $5 \%(0.05)$ or $\mathrm{t}$ count $=3,644>\mathrm{t}$ table $2,039(\mathrm{n}-\mathrm{k}=34-3=31)$. Based on the results obtained then reject $\mathrm{H} 0$ and accept. Ha for transformational leadership variables. Thus, it ispartial thattransformational leadership variables have a significant effect on teacher teaching performance at SMA Dirgantara Center. The results of this study support the results of research conducted by [9][10][11]stating that transformational leadership has an influence in improving teacher performance. It can be stated that when transformational leadership gets better it will improve employee performance.

\section{The Influence of Achievement Motivation on Teaching Performance}

In the study nilai its significance for variable motivational achievement $(0.000)$ is smaller compared to alpha $5 \%(0.05)$ or $\mathrm{t}$ count $=4,808>\mathrm{t}$ table $2,039(\mathrm{n}-\mathrm{k}=50-3=47)$. Based on the results obtained then reject $\mathrm{H} 0$ and accept. Ha for variable motivation to excel. Thus, it ispartial thatthe motivational variables of achievement have a significant effect on the teaching performance of teachers at SMA Dirgantara Center. The results of this study are in line with the results of previous studies conducted by [4][6][5]which state that motivation has an influence in improving an employee's performance.

\section{CONCLUSION}

The results showed that transformational leadership and motivation had a significant and positive influence on teacher performance at SMA Dirgantara Center. The motivation of achievement has the most dominant influence in improving the performance of teachers in SMA Dirgantara Center. Furthermore, the co-efficient determination of $43.4 \%$ is influenced by other variables outside the model. It is expected for further research to look for other variables to determine the model of employee performance implementation.

\section{ACKNOWLEDGMENTS}

The author would like to thank the Director of Lp3M Superior Polytechnic who has provided support both material and no matter. Next to the principal of SMA Dirgantara Center or Mr. Sidirman, SE.,M.Si who has allowed the authors to obtain research data.

\section{REFERENCES}

[1] Nasib, "Pengaruh Gaya Kepemimpinan Dan Budaya Organisasi Terhadap Kinerja Karyawan Pada PT. Pembangunan Perumahan (Perseroan) Tbk Medan," Bisman Info, vol. 3, no. 3, pp. 1-12, 2016.

[2] I. L. Nasib, "Leadership Role Iin The Commitment And Performance of Employees InThe Regional Company Of Medan," Int. J. Innov. Multidiscip. F., vol. 6, no. 8, pp. 58-63, 2020.

[3] N. S. Chaniago, "Pengaruh Insentif dan Gaya Kepemimpinan Terhadap Semangat Kerja Karyawan Pada PDAM Tirtanadi Medan," Abdi Ilmu, vol. 1, no. 1, pp. 63-76, 2018.

[4] S. C. S. A. Y. Nasib, "Optimalisasi Prestasi Kerja Melalui Peningkatan Disiplin, Motivasi Dan Lingkungan Kerja Pada PT. Vamrer Jaya Abadi Medan," in The 2nd Interntional Conference on Politics of Islamic Development, 2019, no. April, pp. 192-201.

[5] Martin, "Job Satisfaction Analysis Through Motivation and Organizational Culture Supervision, Motivation and Organizational Culture," J. Soc. Sci. Jo Job, vol. 1, no. 3, pp. 66-69, 2020. 
[6] Martin, "Job Satisfaction Optimization by Work Atmosphere , Stress of Work , and Work Motivation," Int. J. Innov. Sci. Res. Technol., vol. 5, no. 5, pp. 110-113, 2020.

[7] Sugiyono, Metode Penelitian Kuantitatif kualitatif R\&D, Bandung. 2015.

[8] Sugiyono, metodelogi penelitian kuantitatif,kualitatifdan R\&D. 2016.

[9] A. P. A. S. R. Priamahendra, "Pengaruh Gaya Kepemimpinan Transactional, Transformational, Authentic Dan Authoritarian Terhadap Kinerja Guru Madrasah Tsanawiyah Di Kudus," Al-Tanzim J. Manaj. Pendidik. Islam, vol. 4, no. 1, pp. 70-80, 2020.

[10] D. P. R. E. M. R. E. Putra, "Pengaruh Kepemimpinan Transformasional Terhadap Keinovatifan Guru SMA Negeri Kota Lubuklinggau," Alignment J. Adm. Educ. Manag., vol. 8, no. 5, p. 55, 2019.

[11] A. C. P. R. D. P. C. Yohana, "Gaya Kepemimpinan Transformasional Kepala Sekolah dan Kinerja Guru SMK Swasta di Jakarta Timur," J. Pendidik. Ekon. Dan Bisnis, vol. 5, no. 2, pp. 148-161, 2017. 